\title{
Doublesex- and Mab-3-Related Transcription Factor 1
}

National Cancer Institute

\section{Source}

National Cancer Institute. Doublesex-and Mab-3-Related Transcription Factor 1. NCI

Thesaurus. Code C99656.

Doublesex- and mab-3-related transcription factor 1 (373 aa, $\sim 39 \mathrm{kDa}$ ) is encoded by the human DMRT 1 gene. This protein plays a role in embryonic development. 